Lundysheva Olga,

Turanskaya Anna

\title{
Brāhmī glosses of the Uyghur blockprint of Sitātapatrā dhārạ̣i kept in the IOM, RAS
}

Abstract: This paper deals with the fragment of one of the blockprint Sitātapatrā editions that belongs to the Serindia Collection of the Institute of Oriental Manuscripts of the Russian Academy of Sciences at St. Petersburg. The authors focuse on Brāhmī parts included into the Uyghur text. Some observations on the correlation of Uygur script signs and akśaras in Brāhmī are made. The Chart of akśaras found in the blockprint is attached. Key words: Brāhmī akśara chart, Brāhmī glosses, Old Uyghur Sitātapatrā blockprint.

Sitātapatrā (literally 'Goddess with the white parasol') became one of the highly honoured female deities in the Mahāyāna and Vajrayāna Buddhist tradition. Text dedicated to this goddess Ärya sarva-tathhāgata-uṣnịṣasitātapatrāa-aparājitā nāma-dhāraṇ̄ (literally "White umbrella one' goddess who will protect all devotees from evil", also known under the short name Sitātapatrā dhārañ̄ $)$ was translated into numerous languages of Central Asia as it was regarded as a kind of protection against any negative influence of life or evil. It was translated several times into Chinese, Tibetan and Mongolian. Two Sitātapatrā texts in Khotanese sources are known.

The text became widely spread among the Uyghurs during the era of the Mongol empire (1206-1368). One can suppose the great popularity of the Vidyārājṇ̄ -sitātapatrā-sūtra (Uyg. avišlar iligi sitadapatri sudur) among the Uyghurs as it was blockprinted at least two times under the patronage of the Yuan emperor's family. ${ }^{1}$ The above mentioned editions look almost similar

\footnotetext{
(C) Olga Vladimirovna Lundysheva, Institute of Oriental Manuscripts, Russian Academy of Sciences

(C) Anna Turanskaya, Institute of Oriental Manuscripts, Russian Academy of Sciences

${ }^{1}$ Professor Peter Zieme was the first to notice that the fragments kept in Berlin and Russian collections are from the different blockprint editions (ZIEME 1985, 171). Some researchers assume the excistence of even more editions (PORCIÓ 2003, 93).
} 
and differ mostly in page size. ${ }^{2}$ What is curious, however, is that both editions have Brāhmī parts included. ${ }^{3}$ These inserted glosses pertain to Nothern Turkistan Brāhmī (type B, subtype u) according to the Sander's classification. $^{4}$ They are inserted interlineally and arranged vertically, probably, for reader's convenience.

16 pages of one of the blockprint editions are preserved in the collection of the Institute of Oriental Manuscripts of the Russian Academy of Sciences (IOM, RAS) under the call number SI 4502 (M/5, inv. 4558). They were obtained by a famous Russian scholar S.E. Malov in Turfan during his second expedition in 1913-1915. Later, according to the label attached to the text, "on July 28, 1952, they were granted to the Department of Oriental manuscripts of the Institute Oriental Studies of the Academy of Sciences of the USSR". While the text of the blockprint was published by S.E. Malov in $1930,{ }^{5}$ Brāhmī glosses incorporated into it have never been paid attention.

The present article focuses on the Brāhmī parts included into the Uyghur text. The aim of the article is to provide the list of Brāhmī parts found in the fragments kept in the collection of the IOM, RAS (in the order as they appear in the text), as also the illustrative material that could be used in future research works (chart of akśaras used).

On the territory of the Tarim Basin (Xinjiang, China) Brāhmī script was used by the Turkic people for writing down religious texts as also pilgrim graffiti inscriptions. ${ }^{6}$ Turkic texts could be written in Brāhmī script ${ }^{7}$ or include Brāhmī parts. These Brāhmī parts could be integral components of the text (with the corresponding translation into Uyghur or without it) or interpolations for Buddhist names, terms and mantras that were inserted on the left of the main line of the text. Most of interpolations of this kind were added to the printed texts which are all dated to the Mongolian period. ${ }^{8}$

\footnotetext{
${ }^{2}$ The collation of editions has shown that they have some minor textual differences.

${ }^{3}$ One should note that the majority of Uyghur Buddhist texts that contain Brāhmī glosses are blockprints.

${ }_{5}^{4}$ SANDER 1968, charts 29-40.

${ }^{5}$ MALOV 1930. The publication includes the text printed in Uyghur script (the transliteration is absent) and translation that needs correction as the majority of the buddist terms had not been translated carefully. Moreover the article was published without a detailed archeological and codicological description or facsimile.

${ }^{6}$ The lay pilgrim inscription is described in details in MAUE 1996, 20; Zieme 1984, 335.

${ }^{7}$ Maue 1996, XXXV, 1, 174.

${ }^{8}$ Dișasvastikāsūtra kept in the IOM, RAS is a rare exception. The research on Brāhmī glosses in this text is being done by O. Lundysheva at the moment. Results of this research are to be published soon.
} 
The researchers who made analisys of these glosses in the Old Uyghur Buddhist texts, in particular blockprints, paid attention to the fact that most of them do not correspond to their Sanskrit original exactly, but to a form borrowed by Tocharian. ${ }^{9}$ Moreover the numerous mistakes and erroneous forms (not corresponding with Sanskrit or Tocharian variants) in glossary apparently could be explained by the fact that the scribes of the Brāhmī glosses didin't use the Sanskrit original texts relying on the writing in Uyghur script. ${ }^{10}$

So what was the meaning of these glosses? What was the purpose of inserting them into the texts? ${ }^{11}$ Analising the Brāhmī glosses in the Uyghur blockprint edition of Sitātapatrā dhāraṇ̄ kept in the Berlin collection Tibor Porció outlines that they were used as a kind of 'collecting religious merit', 'exhibiting religious erudition' and thus supporting the authenticity of particular text. ${ }^{12}$

Although all these presumptions are plausible ${ }^{13}$ it seems more likely that their main function was more pragmatic. The Brāhmī glosses represent nothing 'but the mere transcription of the erroneous Uyghur forms'. ${ }^{14}$ Apparently the scribes realized the inadequacy of the Uyghur script in unambiguous transmission of words of Indian origin and challenges that less erudite and sophisticated readers could face.

The manuscript copy of Diśasvastikāsūtra kept in St. Petersburg collection (IOM, RAS) is an illustrative example of usage such kind of transcription. Brāhmī glosses in this manuscript are written in alsmost illegible cursive script that was probably clear only to the person who wrote them down. The ductus gives us enough evidences to suppose that they were written by different people and at varying times (as they are written both vertically and horizontally). Thus it is possible to presume that such tradition of glossing was an inalienable part of the Old Uyghur writing culture.

Moreover in the above mentioned blockprints there are no Brāhmī glosses for words that apparently became widely spread among the Uyghur Buddhist devotees, e.g. vajra, buddha, dhāran̄i etc. In addition some Sanskrit words

${ }^{9}$ However Brāhmī glosses in the manuscript Dasiakarmapathāvadānamālā from Hami could be considered to be a rare exception (LAUT 1996, 191-194; GENG, LAUT, WILKENS 2005, 73; YAKUB 2006, 28-34). The Tocharian influence on the glosses' form is described by ShŌGAITO 1978, 84; Porció 2003; KASAI 2015.

${ }^{10}$ This fact was repeatedly noted by researchers (LAUT 1996, 114; ZIEME 1985, 336).

${ }^{11}$ In comparosin, for example, with the Mongolian tradition where glosses show the tense connection with the Tibetan original texts.

${ }^{12}$ PORCIÓ 2003, 94.

${ }^{13}$ These functions are more likely to be more important for Uyghur texts with Brāhmī integral components accompanied by translations into Uyghur or without them.

${ }^{14}$ PORCIÓ 2003, 95. 
written in Uyghur are accompanied not by the whole word re-transcription but its part (e.g. in Sitātapatrā dhāraṇī - kșas、 (r'kṣs’z) for rākșasa). Besides there is no uniform orthography in one text (e.g. 'l'mp' n'y - alambāni, ' 'l'mp' n'-alambāna) and the spelling differs in accordance to the Uyghur.

In the concerned blockprint kept in the IOM, RAS Brāhmī parts appear in the following order: ${ }^{15}$

\begin{tabular}{|c|c|c|c|c|}
\hline $\begin{array}{l}\text { Uyghur } \\
\text { transcription }\end{array}$ & $\begin{array}{c}\text { Uyghur } \\
\text { ransliteration }\end{array}$ & $\begin{array}{c}\text { Brahmi } \\
\text { glosses }\end{array}$ & Tocharian & Sanskrit \\
\hline garude & k'rwdy & garuḍi & garuḍe*16 & garuḍa \\
\hline asure & "'swry & asuri & asūre & asura \\
\hline rakşaz & r'kṣ̆’z & kșas & rākṣatse* & rākṣasa \\
\hline ganḍar - ve & k'nt'r - vy & gandharvi & gandharve* & gandharva \\
\hline garude & k'rwty & garuḍi & garuḍe* & garuḍa \\
\hline marute & m'rwty & maruḍi & - & maruta \\
\hline kinare & kyń’ry & kinari & kinnare* & kiṃnara \\
\hline mahorage & m'qwr'ky & mahoraki & - & mahoraga \\
\hline manuşi & m'nwș̌y & mānuṣi & - & manuṣya \\
\hline amanuži & '’m'nwz y & amānuṣi & - & amanuṣya \\
\hline pret & pryt & pret、 & prete* & preta \\
\hline pişaçe & pyș̌ čy & piśaci & - & Piśāca \\
\hline $\begin{array}{l}\text { kum- panḍe } \\
\text { puțane }\end{array}$ & $\begin{array}{l}\text { kwm - p'ńty } \\
\text { pwd'ńy }\end{array}$ & $\begin{array}{l}\text { ku - mbhāṇụi } \\
\text { putani }\end{array}$ & $\begin{array}{l}\text { kumbhāṃṇ̣e** } \\
\text { pūtane* }\end{array}$ & $\begin{array}{l}\text { Kumbhāṇḍa } \\
\text { pūtana }\end{array}$ \\
\hline kataputane & k't'pwd'ny & kațaputani & kațapūtane* & kațapūtana \\
\hline skanḍa & sk'ńt' & skandha & - & Skanda \\
\hline utmada & 'wtm'd' & udmāda & - & unmāda \\
\hline apasmar & '’p'sm'r & apasmra & apasmār & apasmāra \\
\hline mahapaşu- & m'q'p'ș̌w & mahāpaśu- & - & mahāpaśu \\
\hline $\begin{array}{l}\text {-patị } \\
\text { mahakade }\end{array}$ & $\begin{array}{l}\text { p'dy } \\
\text { m'q'k'dy }\end{array}$ & $\begin{array}{l}\text {-pati } \\
\text { mahākadi }\end{array}$ & - & $\begin{array}{l}\text { pati } \\
\text { mahākāla }\end{array}$ \\
\hline kapali & k'p'ly & kapali & - & kāpālika \\
\hline şabari & ș’p'ry & śabari & - & śavarī \\
\hline bukkakasi & pwkk'k'sy & pukkasi & - & pukkasī \\
\hline atarvana & 't'rv'ń' & atharvaṇa & - & àtharvaṇa \\
\hline vinayike & vyn்’yyky & vināyiki & - winai & vināyaka \\
\hline kumare & kwm'ry & kumāri & - & kumāra \\
\hline maharaç & m'ä'r' & mahārāc & - & mahārāja \\
\hline
\end{tabular}

${ }^{15}$ Reasearch of the orthograpphy peculiarities of the Brāhmī glosses in the Berlin blockprint was done by T. Porció (PORCIÓ 2003). They are the same in the fragment of the blockprint from St. Petersburg collection. The majority of words met in the fragments of the blockprints in both collection coincide. In some cases they differ in spelling. Mostly, the differences are represented in the vowel length, (e.g. garuḍi - garūḍi) or different consonants for transcription (e.g. kinari - kinnari, parivracaki - parivrajaki).

${ }^{16}$ The mark "*" is used for words that are not found till now in the Tocharian manuscript fragments, but reconstructed. 
Being a ritual text Sitātapatrā-dhāraṇ̄ represents a string of mantras and dhāranīs enclosed in the narrative frame. They are considered to be the most important and sacred part for the devotees. ${ }^{17}$ As their efficiency is in sound rather than meaning they were never translated but given in transcription. So no wonder that the longest Brāhmī part used in the text is dhāranī. The 16 pages of text in St. Petersburg collection contain only one mantra.

The Sanskrit mantra om ṛși-gana-prașastana-sarva-tathāgatoṣnịṣa-sitātapatre hūm trūm hrì ștom jambhanakari hūm trūm is transcribed in the following way:

\begin{tabular}{|c|c|c|c|c|c|c|}
\hline $\begin{array}{l}\text { 'wwm } \\
\text { om、 }\end{array}$ & $\begin{array}{l}\text { ’yrž y } \\
\text { rṣi }\end{array}$ & $\begin{array}{l}\text { k'ń' } \\
\text { gana }\end{array}$ & $\begin{array}{l}\operatorname{pr}[\ldots] \\
\operatorname{pr}[\text { așastana }]\end{array}$ & $\begin{array}{l}\text { s'rv' } \\
\text { sarva }\end{array}$ & $\begin{array}{l}\text { t't'k'd' } \\
\text { tathāgatā }\end{array}$ & $\begin{array}{l}\text { 'wș̃nyš' } \\
\text { uṣnișāā }\end{array}$ \\
\hline $\begin{array}{l}\text { syt'd'p'tyry } \\
\text { sitātapatr[e] }\end{array}$ & $\begin{array}{l}\text { [*qwnk] } \\
\text { [hūṃ] }\end{array}$ & $\begin{array}{l}\text { twrwm } \\
\text { drum }\end{array}$ & $\begin{array}{l}\text { q̈yryș̌dwrwm } \\
\text { hri șțrom }\end{array}$ & $\begin{array}{l}\text { č'mp'k'ry } \\
\text { cambhanakari }\end{array}$ & $\begin{array}{l}\text { qwnk } \\
\text { hūṃ }\end{array}$ & $\begin{array}{l}\text { twrwm } \\
\text { drum }\end{array}$ \\
\hline
\end{tabular}

Although Brāhmī parts are quite short they provide enough material to make some observations on the correlation of Uyghur script signs and akśaras in Brāhmī. On the basis of the fragments of the Old Uyghur blockprint of Sitātapatrā dhāraṇī one may see the Brāhmī signs that were used for transcription:

\begin{tabular}{|c|c|}
\hline \multicolumn{2}{|c|}{ Initial vowels } \\
\hline Uygur words & Brāhmī glosses \\
\hline$"$ & $\mathrm{a}$ \\
\hline 'w & $\mathrm{u}$ \\
\hline 'ww & o \\
\hline \multicolumn{2}{|c|}{ Syllable vowels } \\
\hline , & $\mathrm{a} / \overline{\mathrm{a}}$ \\
\hline $\mathrm{y}$ & $\mathrm{i} / \mathrm{e}$ \\
\hline $\mathrm{w}$ & $\mathrm{u} / \overline{\mathrm{u}} / \mathrm{o}$ \\
\hline 'y & ai \\
\hline ww & $\mathrm{au}$ \\
\hline \multicolumn{2}{|c|}{ Consonants } \\
\hline $\mathrm{k}$ & $\mathrm{k}_{\mathfrak{i}} / \mathrm{kh} / \mathrm{g} / \mathrm{gh} / \mathrm{h}$ \\
\hline q & $\mathrm{h}$ \\
\hline $\mathrm{c}$ & $\mathrm{cj}$ \\
\hline$t / d$ & $\underline{t} / \mathrm{d} / \mathrm{t} / \mathrm{th} / \mathrm{d} / \mathrm{dh} / \mathrm{ddh}$ \\
\hline $\mathrm{n}$ & $\mathrm{n} / \mathrm{n} / \mathrm{nn} / \mathrm{m}$ \\
\hline $\mathrm{m}$ & $\mathrm{m} / \mathrm{m}_{\mathfrak{i}} / \mathrm{m}$ \\
\hline
\end{tabular}

${ }^{17}$ The narrative text is used as a kind of detailed explanation of the usage of the corresponding mantras. 


\begin{tabular}{|c|c|}
\hline $\mathrm{p}$ & $\mathrm{p} / \mathrm{ph} / \mathrm{b} / \mathrm{bh}$ \\
\hline $\mathrm{y}$ & $\mathrm{y} / \mathrm{yi}$ \\
\hline $\mathrm{r}$ & $\mathrm{r}$ \\
\hline 1 & 1 \\
\hline $\mathrm{V}$ & $\mathrm{V}$ \\
\hline $\mathrm{s}$ & $\mathrm{s}$ \\
\hline$\check{\text { š }}$ & śs \\
\hline $\mathrm{Z}$ & $\mathrm{s}_{\dot{\gamma}} / \mathrm{s}$ \\
\hline \multicolumn{2}{|c|}{ Consonant blend } \\
\hline $\mathrm{kn}$ & ghn \\
\hline ky & kya \\
\hline $\mathrm{ks} / \mathrm{ks}$ & kș \\
\hline tv & tv / dhv \\
\hline nkk & $\dot{\mathrm{n} k} / \dot{\mathrm{n}} \mathrm{kh} / \dot{\mathrm{n} g}$ \\
\hline nc & ñc \\
\hline $\mathrm{nt}$ & nt / ṇ̣ / nd / ndh \\
\hline $\mathrm{mp}$ & $\mathrm{mp} / \mathrm{mbh}$ \\
\hline py & bhy \\
\hline $\mathrm{pr}$ & $\mathrm{pr}$ \\
\hline $\mathrm{rk}$ & $\mathrm{rg}$ \\
\hline rv & rv \\
\hline str & str \\
\hline šn & ș̣n \\
\hline$\check{S \check{V}}$ & Śv \\
\hline \multicolumn{2}{|c|}{ Stable syllables } \\
\hline k'r & $\mathrm{kr}$ \\
\hline kyr & gra \\
\hline gyr & hri \\
\hline cyr & jra \\
\hline tyk & tyek \\
\hline t'r & $\operatorname{tr}$ \\
\hline twr & dru \\
\hline tyr & tri \\
\hline pyr & bra / bhr \\
\hline r'm & $\mathrm{rma}$ \\
\hline v'r & vra \\
\hline swr & sro \\
\hline šdwr & șțro \\
\hline \multicolumn{2}{|c|}{ Stable spelling } \\
\hline durum & ștrom \\
\hline pud & buddha \\
\hline $\mathrm{pt}$ & phat: \\
\hline
\end{tabular}


What is more important is that material provided in the blockprints can be organized into the summary chart of Brāhmī akśaras used by the Uyghurs. While in the manuscripts they are fused together and its extremely difficult to devide them from each other in blockprints they are 90-degree turned, easy-to-read and represent a kind of 'average variat' for the writing tradition on the whole. Thus these charts are useful for analisys and research of the Brāhmī glosses in the Old Uyghur manuscripts.

\section{Appendix}

Akshara List of the blockprint

\begin{tabular}{|c|c|c|c|c|c|c|c|c|c|}
\hline- & $\mathrm{a}$ & $\overline{\mathrm{a}}$ & $\mathrm{i}$ & $\overline{\mathrm{i}}$ & $\mathrm{u}$ & $\overline{\mathrm{u}}$ & $r$ & e & 0 \\
\hline- & & & & & 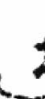 & & $\approx$ & & $\alpha$ \\
\hline k & & & & & & & & & \\
\hline $\mathrm{g}$ & $\eta$ & & & & & & & & \\
\hline c & & & & & & & & & \\
\hline$t$ & 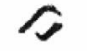 & & & & & & & & \\
\hline d & & & & & & & & & \\
\hline ṇ & $M$ & & $\sim$ & & & & & & \\
\hline $\mathrm{t}$ & 3 & & $R$ & & & & $\not$ & & \\
\hline th & $\theta$ & & & & & & & & \\
\hline
\end{tabular}


$-19$

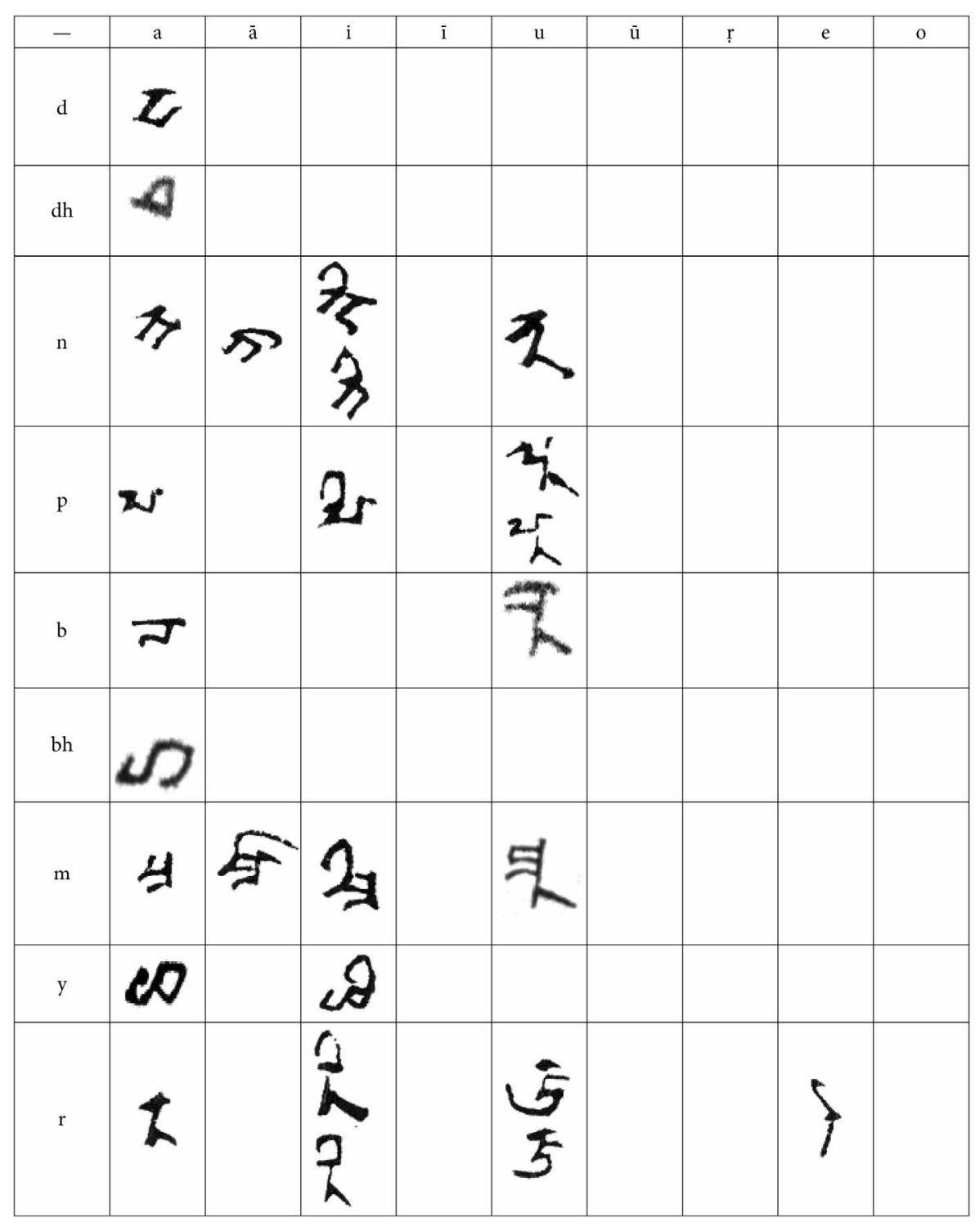


20
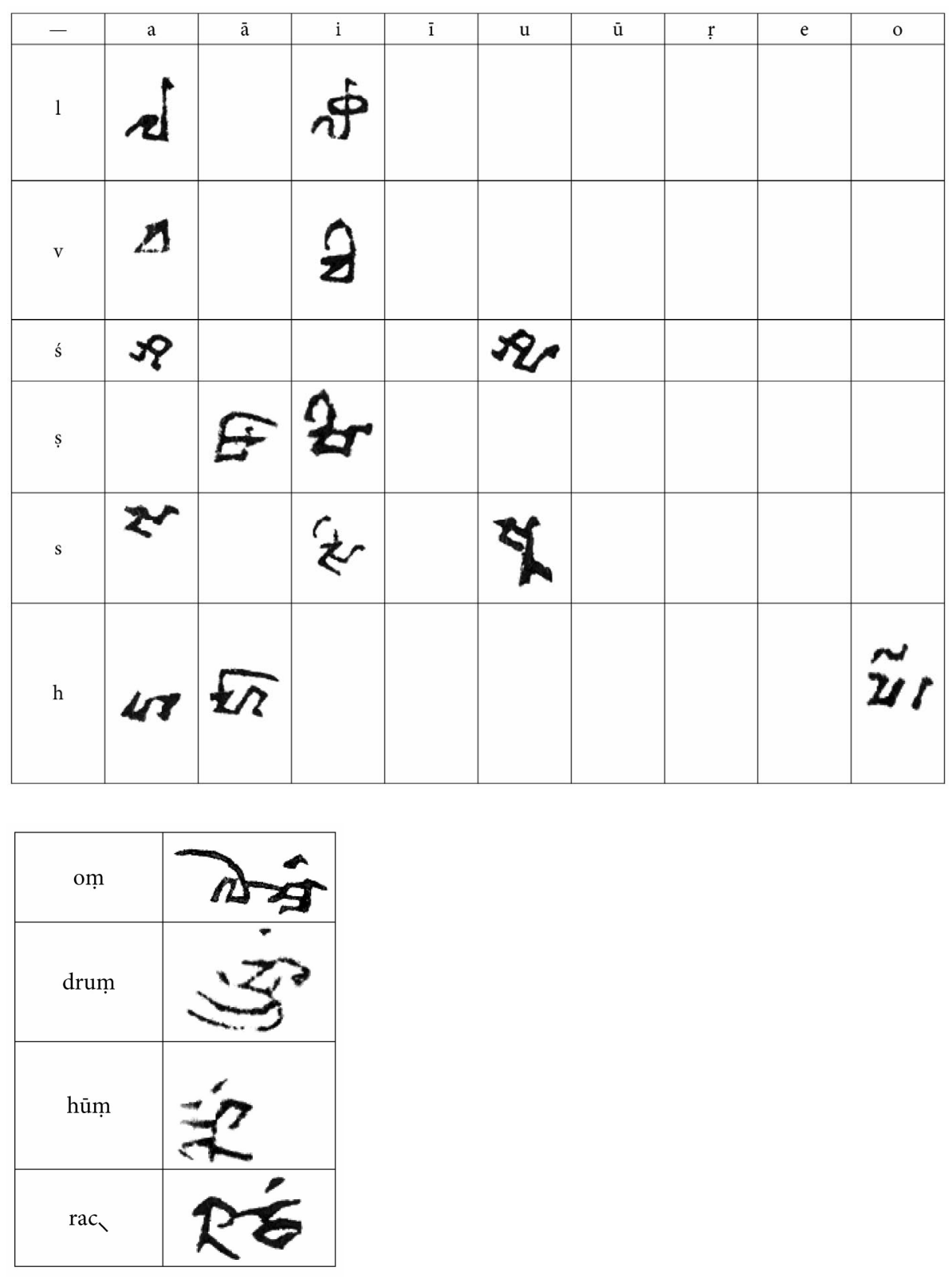


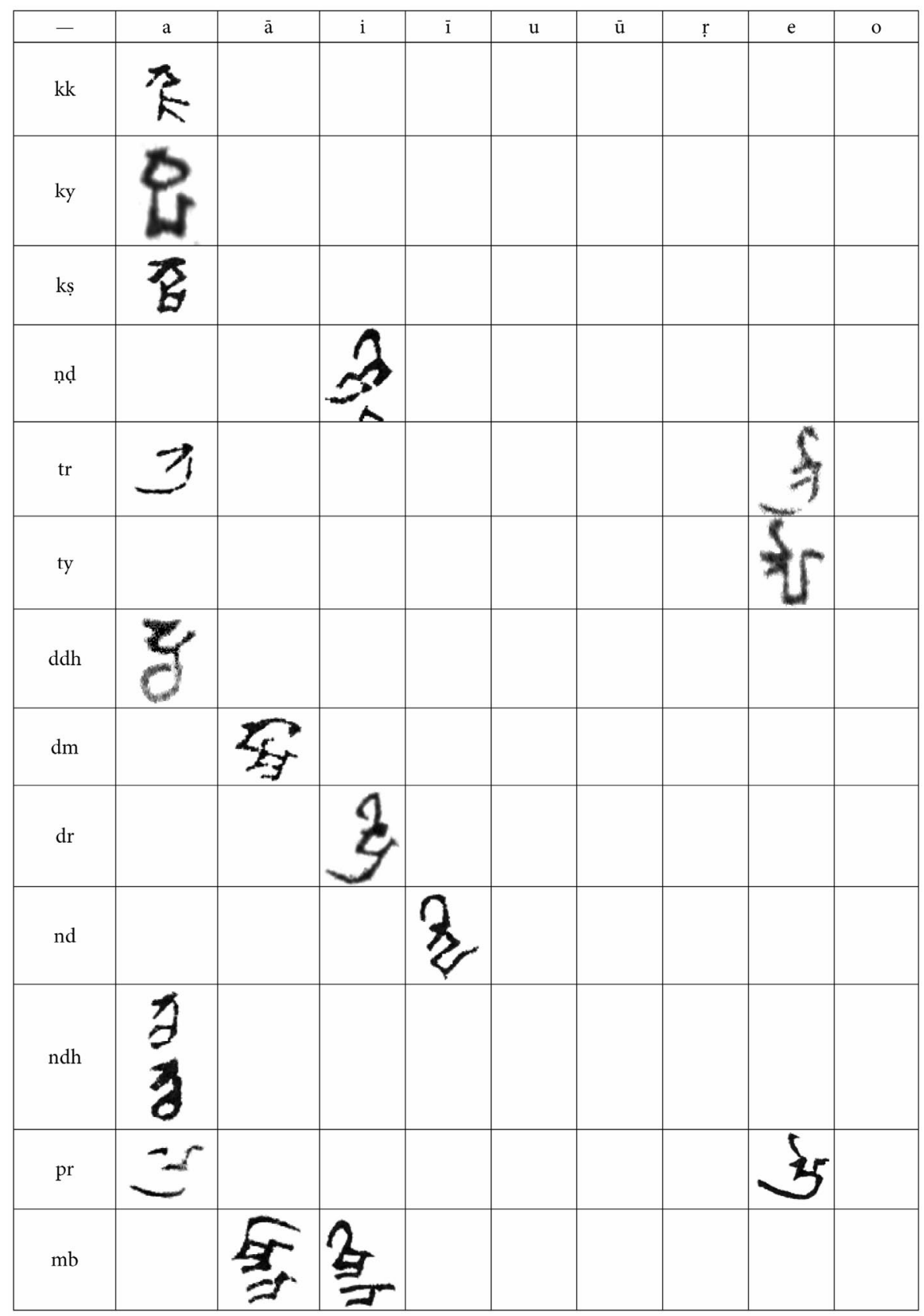


22

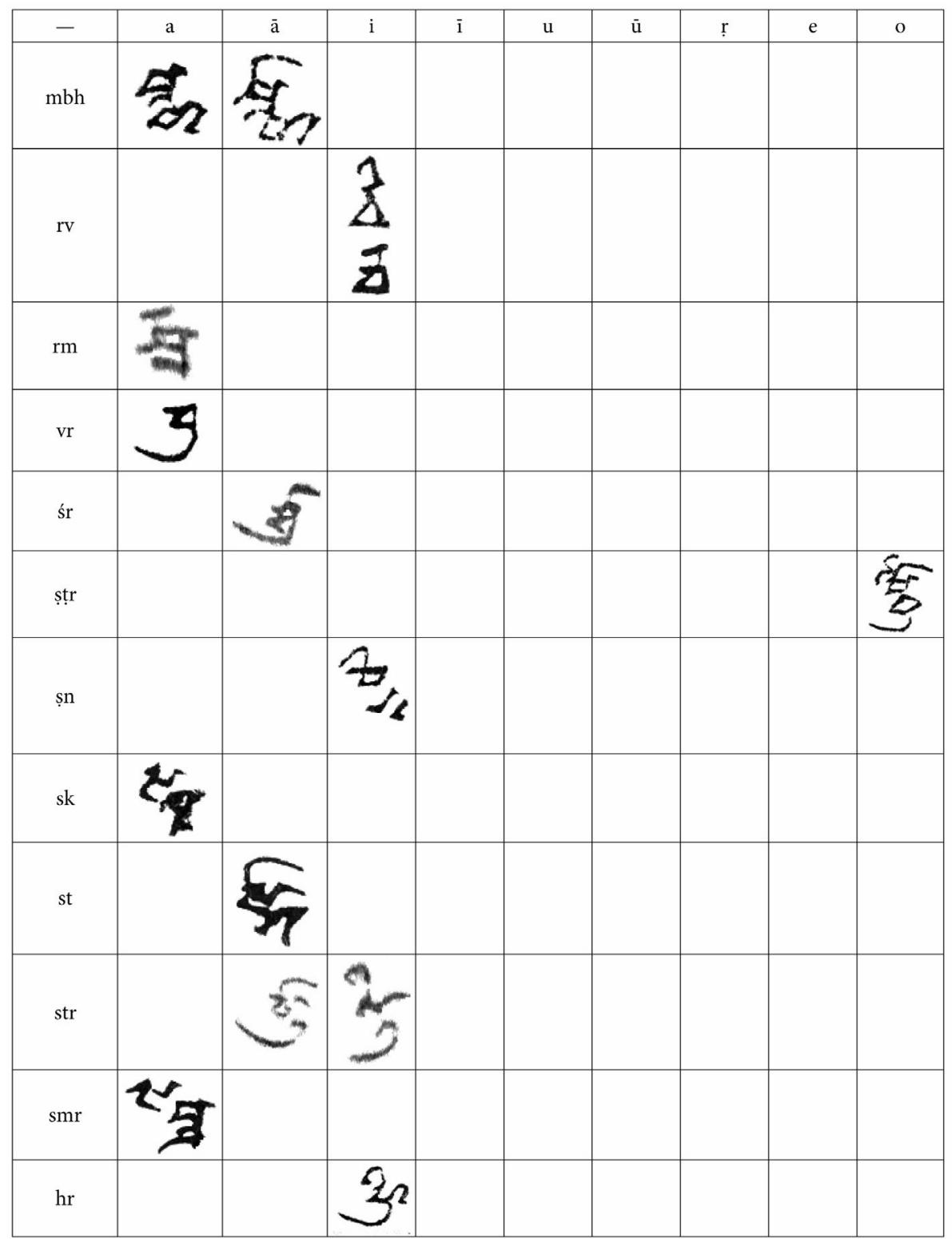




\section{References}

Geng, Shimin and Laut, Jens Peter and Wilkens, Jens 2005: "Fragmente der uigurischen Daśakarmapathāvadānamālā aus Hami (Teil 1)". Ural-Altaische Jahrbüčher Neue Folge 19, 72-121.

KASAI, Yukio 2015: "Sanskrit Word Forms Written in Brāhmī Script in the Old Uyghur Buddhist Texts". Journal of the International Assosiation of Buddhist Studies, vol. 38, 401-422.

LAUT, Jens Peter 1996: "Zu neuen Hami-Handschriften eines alttürkischen buddhistischen Legendenzyklus". Turfan, Khotan anf Dunhuang. Vorträge der Tagung "Annemarie v. Gabain und die Turfanforschung”, veranstaltet von der Berlin-Brandenburgischrn Akademie der Wissenschaften in Berlin. 9.-12.12.1994. Berlin, 189-199.

Maue, Dieter 1996: Alttürkische Handschriften, Teil I, Dokumente in Brāhmī und tibetischer Schrift. Stuttgart: Steiner.

MALOv S.E. 1930: "Sitātapatrā-dhāraṇī v ujgurskoj redakcii" [Sitātapatrā-dhāraṇī in Uighur version]. Doklady Akademii nauk SSSR, no. 5. Moscow: Izdatel'stvo Akademii Nauk SSSR, 88-94.

Porció, Tibor 2003: "On the Brāhmī Glosses of the Uyghur Sitātapatrā Text". Central Asiatic Journal. Ed. by Giovanni Stary. 47(1). Wiesbaden: Harrassowitz Verlag, 91-109.

SANDER, Lore 1968: Paläographisches zu den Sanskrithandschriften der Berliner Turfansammlung. Wiesbaden: Franz Steiner Verlag.

SHŌGAITO, Masahiro 1978: “古代ウイグル語におけるインド来源借用語彙の導入経路 について” [On the routes of the loan words of Indic origin in the Old Uighur language] アジア・アフリカ語の計数研究 [Journal of Asian and African Studies] 15 (1978), 79110.

YAKUB, Abdurishid 2006: Yakub A. Dišastvustik. Eine altuigurische Bearbeitung einer Legende aus dem Catusparișat-sūtra. Wiesbaden: Harrasowitz.

ZIEME, Peter 1984: "Zur Verwendung der Brāhmī -Schrift bei den Uiguren”. Altorientalische Forschungen, no. 11. Berlin: Akademie Verlag, 331-346.

ZIEME, Peter 1985: Buddhistische Stabreimdichtungen der Uiguren. (Berliner Turfantexte 13). Berlin: Akademie Verlag. 